\title{
The Role of Trade Unions in Building Resistance: Theoretical, Historical and Comparative Perspectives
}

Ralph Darlington

\section{Introduction}

For some hostile commentators trade unions (or 'labour' unions as they are termed in the US) have become a 'dinosaur' whose justifiable role in the past of protecting vulnerable and exploited low-paid workers has increasingly become irrelevant within the transformed world of employment relations and Human Resource Management of the twenty-first century. But for many millions of workers the durability of trade unionism, and its continuing quintessential function of attempting to organise to defend their collective interests within the workplace and society more broadly, has undoubtedly been reinforced by recent developments across the world. Thus not only did independent trade unions in early 2011 play a crucial important contributory role to popular revolutions and uprising to overthrow repressive regimes in the Arab world, but in many countries in western Europe and elsewhere over the last 2-3 years there has been the resurgence of collective trade union mobilisation and resistance to the austerity measures governments have attempted to impose amidst the global financial crisis. Nowhere has this been more evident than in Greece where there have been repeated one-day general strikes involving millions of workers protesting at the impact of austerity on their pay, conditions, jobs and pensions, combined with repeated mass demonstrations in Athens. Likewise the attempt to shift the burden of the biggest economic and financial crisis of post-war capitalism onto workers' shoulders has provoked mass public sector or general strikes in France, Spain, Italy, Belgium and Britain, while in the United States there was a three-week long occupation of Wisconsin's state government building in opposition to a Republican-based law curbing collective bargaining rights, with protests spreading from Indiana to Oklahoma. Such developments have opened up the possibilities for an upswing in trade union fortunes generally across the world.

However, the picture is varied, the revival of trade union organising and mobilising capacities has been partial, and there remain formidable economic, political and social constraints to unions' abilities to defend their members from the ravages of corporate globalisation and neo-liberalism. Moreover, over the last 30 years in many advanced industrialised countries around the world, but notably in the US and Europe, trade unions have been in decline, if not 'crisis'. Declining membership, density, bargaining coverage, strike levels, and political influence have all underlined their apparent inability to 'renew' themselves, with unions often tending to rely on institutional supports rather than developing proactive strategies for confronting their predicament. Indeed, while unions have suffered the blows of neo-liberalism they have generally proved unable to construct an effective industrial and political challenge or counter-response to turn back the tide.

Some have even willingly cooperated with or provided qualified support to neoliberalism, and have merely sought to safeguard workers' interests from its worst effects but to the detriment of other workers elsewhere. Others have also accepted neo-liberalism in practice, albeit attempting to pursue sympathetic strategic state and supra-state action to 
adjust market pressures (for example in relation to privatisation), alongside the advocacy of a restoration of modified social democracy with Keynesian economics. Only a small minority of unions have appraised neo-liberalism as antipathetic to strong trade unionism and advocated anti-capitalist and radical socialist solutions on a national and global basis as an alternative, combined with militant collective union mobilisation to stave off its effects (Gall et al, 2011). Thus the extent to which the 'Age of Austerity' unleashed by the global financial crisis of 2009, and the revival of trade union struggle it has recently provoked in many countries, provides not merely a challenge but also an opportunity for unions to qualitatively re-build their powers of resistance and advance their organisation is an open question, but one which is likely to be resolved with dramatic long-term consequences for years to come.

Such challenges and opportunities also make it imperative for broader reflection and revaluation as to the limits and potential of trade unions as anti-capitalist forms of organisation. In this respect, although Marx and Engels never developed a systematic and generalisable theoretical analysis of trade unions, they were nonetheless close observers and frequent commentators on the development and struggles of British trade unionism over 50 years in its formative period of the nineteenth century, and in the process made some incisive insights. Undoubtedly their main contribution was to draw attention to the highly contradictory nature of trade unionism, which both expressed and contained working class resistance to capitalism, such that the unions were at one and the same time agencies of working class conflict and accommodation with the power of capital.

On the one hand, they mobilise the collective strength which workers have in the workplace, and through the battles fought over wages, jobs, conditions and hours, workers via their trade unions can gain the organisation, confidence and class consciousness to challenge and ultimately overthrow the capitalist system; as 'schools of war' trade unions can make workers aware of their ability to completely transform society (Engels, 1969: 251). On the other hand, trade unions tend to operate within the framework of capitalism; they seek not to overthrow it, but merely to improve workers' position within the context of the existing system; their aim is not to end exploitation but to re-negotiate the terms on which workers are exploited. As Marx (1970: 225) put it 'They are fighting with effects, but not with the causes of those effects':

Yet significantly the dual nature of trade unionism is not always equally balanced. The relative weight of conflict and accommodation within capitalism is deeply affected by the situation in which the unions operate, namely the dramatic changes in the level of class struggle and in the consciousness and fighting strength of the working class at different periods, and it was this which affected Marx and Engels' apparent contradictory assessments of the nature of trade unionism (Hyman, 1971; 2001: 18; Cliff and Gluckstein, 1986: 26-34; Kelly, 1988: 11). Building on the work of classical Marxism, this chapter examines this contradictory nature of trade unionism, on the one hand its role in building resistance to capitalism, and on the other hand in limiting such resistance within the context of the existing system. In the process it explores the different types of trade union model of resistance that have developed historically in different countries around the world, as well as some of the contemporary challenges they face in a context of neoliberal globalisation and austerity. While the chapter prioritises an analytical overview, it also provides some concrete examples of processes and developments where appropriate. 


\section{Basic Defence Organisations of the Workers}

Trade unions are historical products of workers' everyday experience of capitalism, an organisational expression of the irreconcilability of labour and capital. They embody workers' resistance (however tentative) to capitalist domination over the employment relationship, challenging employers' 'right' to hire labour at the cheapest price and to deploy, manage and control labour irrespective of workers' own wishes and aspirations (Hyman, 1975a: 160). In the process, trade unions provide the means by which workers can attempt to gain some minimal degree of counter-control over the terms of their employment and the conditions under which they work. It is for this reason that unionisation has invariably emerged historically only in the face of hostile opposition by employers.

To fully understand the direct link between trade unionism and capitalism we need to recall some of the main distinguishing features of the employment relationship. First, in a market economy labour is in one sense a commodity to be bought and sold like any other. In effect, in return for their wages, employees surrender their capacity to work, which in Marxist terminology is known as 'labour power'. The sale of labour power - the fixing of the workers' income and hence the employer's labour costs - necessarily involves an objective basis for conflict. While it is in the employers' interest to maximise profits by securing labour at the lowest possible economic cost, and to retain workers in employment only so long as they generate a profit, it is employees' interest to sell their labour at the highest possible price and thereby maximise wages. Moreover, the distinction between labour power and the actual product of labour is important to the Marxist charge of 'exploitation' - the notion that it is the difference between the value of goods produced and the value of labour power (wages) which is the source of 'surplus value' (roughly, profit). Thus, trade unionism - in fighting to defend and improve workers' wages - represents a reaction against such economic exploitation, against the extraction of surplus value from workers' labour.

Second, unlike other types of commodity, labour is quite unique. The employment relationship may lay down the wages which the worker receives, but it does not define precisely what will be provided in return. The worker does not agree to expend an exact amount of labour; for the precise tasks to be performed and the nature of acceptable performance can never be fully specified in advance, and anyway the employers want to be able to make flexible use of their labour force as circumstances dictate. Crucially it is the function of management, through an authoritarian structure of discipline and control over work organisation and the exercise of 'performance management', to transform - or more specifically exploit - this capacity into productive activity, to effectively 'utilise' employees for 'their own ends' of generating profit (Hyman, 1980: 304; 1989: 227; Sisson, 2009; 44). As a consequence, there is also a conflict of interest in the performance of work and over the control of the labour process, just as there is over the sale of labour power.

There is an inevitable imperative for employers faced with competitive pressures (or 'value for money' in the public sector) to attempt to alter the 'wage-effort' bargain by constantly seeking to cuts costs, intensify work tasks, introduce more 'flexible' working practices and new labour-saving technologies, and reduce the numbers of workers employed (Hyman, 1989: 228). Yet the nature of the employment relationship is 
contradictory - in as much as employees represent both a cost and an investment compromises inevitably have to be made, such that employers are obliged to attempt to motivate employees not just to follow managers' instructions in an act of subordination but also to exercise their own judgment and initiative (Sisson, 2010: 209). So work effort, like wages, is negotiable - the limits of management authority and employee obedience are always open to a negotiation of order, with more or less constant pressures on and opportunities for the parties to act to adjust the exchange in their favour. It is precisely within this 'frontier of control' (Goodrich, 1975) over which workers and employers battle for supremacy - over wages, work speed and intensity, between pay and work effort, and over compliance with and resistance to managerial control over the labour process - that trade unions can play a fundamentally important role as a basic form of workers' defence organisation.

But trade unionism is not only a collective expression of the fundamental conflict of interest that exists between workers and employers over the terms of conditions of employment; it is also a reflection of the asymmetry or inequality of power between labour and capital. Isolated individual workers have little defence or bargaining power vis-à-vis their employers because the economic strength of the two parties is vastly different. Hence the need for trade unions - a source and medium of power - to reduce competition among workers in the labour market and confront the concentrated economic power of employers with their own organised combination of labour power and solidarity (Hyman, 1980: 321). Through such collective organisation, unions have the power to persuade employers to negotiate with them, to make real the threat of a withdrawal of labour through strike activity, and to ensure there is some collective (rather than unilateral managerial) regulation over the terms and conditions of employment. The logic of trade unionism is to mobilise power to redress the bargaining imbalance between capital and labour and render it more equal.

Thus it was that Marx and Engels were among the first socialists in the nineteenth century to see trade unions as basic defence organisations or 'ramparts for the workers' (Marx, 1973: 150). Unions are based on the idea of class organisation; they help workers to see that 'we are not all in it together', that workers have common interests which are quite distinct and opposed to those of employers. They act to block the smooth passage of capitalist requirements within the workplace (Cohen, 2006: 209) and provide the means by which workers can begin to act to combat exploitation. Their primary function is to secure the things that every worker needs - a job, good wage, safe conditions and decent hours. Their all-inclusive unity, organised around the most basic issues which all workers have in common, is the secret of union power. 'Unity is strength' as the old slogan goes.

Historically the primary day-to-day means by which trade unions have sought to limit the power of employers and attempt to defend and, where possible, improve the terms and conditions of employment of their members, has been collective bargaining. Collective bargaining involves union representatives in a process of negotiation, bargaining and rulemaking with managers, in which each side seeks to apply pressure, including forms of industrial action such as strike activity, to resolve differences between them. It results in a joint regulation of the employment relationship, codified in collective agreements that regulate wages and a wide range of other issues relating to union members' jobs and 
working life. Although in the UK by the late 1970s collective bargaining had become the predominant method used to determine many aspects of the employment relationship, the percentage of the workforce covered by such agreements (more extensive than trade union membership levels per se) has been in steady decline ever since, embracing about a third of workers today, with a similar tendency in many other countries amidst the neo-liberal drive for flexibility. Other means of attempting to regulate or influence aspects of the employment relationship that involve trade union activity include individual representation and joint consultation. In the process 'the constant underlying social purpose of trade unionism is participation in job regulation. But participation is not an end in itself, it is the means of enabling workers to gain more control over their working lives' (Flanders, 1975: 42).

The complexity of the ways in which trade unions have attempted to regulate the employment relationship has been captured by using the metaphor of a double-edged sword (Flanders, 1970: 14). One edge of the sword represents the pursuit of vested interest in as much as their immediate concern is with protecting and improving the pay and conditions of their particular members. But in addition they are a sword of justice because, in defending workers against the arbitrary use of managerial power, they promote democratic involvement (both through internal structures of workplace union representation, as well as participation in collective bargaining machinery) and a strong sense of idealism and social purpose, for example, campaigning for the rights of the most vulnerable in society irrespective of whether they are union members or not. Recent examples of this social dimension include union support for anti-racist campaigns and the defence of migrant workers entering the labour market.

There are four broad classifications that can help to explain the diversity of methods used by unions to achieve their ends (Dundon and Rollinson, 2011: 136-7). First, as we have seen, there is economic regulation, which broadly consists of unions attempting to secure the highest possible real wages and monetary conditions (including overtime, bonus payments, etc) for their members. The evidence suggests that union recognition in a workplace tends to bring with it a higher wage premium for unionised employees compared with non-union workplaces, albeit this can depend on other factors such as the size of the employing organisation, nature of the product market, extent of workers' bargaining power, and the state of the economy and level of unemployment.

Second, there is job regulation, which allows union representatives to become 'joint' authors of the rules and regulations that govern employment in the workplace, thereby limiting managerial freedom of power and decision making authority. These include rules that specify working hours, health and safety and equal opportunities obligations, as well as procedures for handling collective disputes, individual grievances, disciplinary action, disclosure of information and facilities for workplace union representatives.

Third, there is the exercise of power. Clearly the combination of employees within a trade union, and even union recognition by employers, does not necessarily guarantee that they will have the ability to resist the actions of managers. This depends on the power resources they are able to mobilise, with a union's credibility and persuasiveness ultimately underpinned by its potential capacity to take retaliatory action in pursuing its aims. Factors 
that influence unions' powers include, amongst other things, the nature and level of the labour market and product market, workers' scarcity value and ability to disrupt production or service provision, the level of membership density, and the cohesion and degree of solidarity among the workforce.

Fourth, the pursuit beyond the workplace of wider social, economic and political change within society has also been a function of many unions, for example by attempting to persuade governments to devise public policies and enact statutory regulation (over matters such as wage protection and equality of opportunity) that benefit all citizens within society. In many European countries unions have direct links with social-democratic or socialist parties that aspire to be elected to parliament to enact social change. Sometimes the link between unions and such parties takes a formal, institutional shape, as in the case of Britain through union funding and union representation at every level of the party, sometimes an informal one, as in Germany.

Thus trade unions are workers' basic frontline defence organisations against capitalist exploitation in the workplace. They are part of how workers come to see themselves as a class, united in a common interest against the employers, and they provide the collective means through which workers can offset to some extent the arbitrary powers of the employer. But arguably it is through the organisation of strike action - involving the withdrawal of labour by workers - that the real power and strength of trade unionism become most evident.

\section{Trade Unions and Strike Activity}

In the vast majority of cases the collective bargaining process is successful in resolving differences between trade unions and managers arising from conflict over the wage-effort bargain. However, there are times when it is temporarily suspended because agreement cannot be reached. On these occasions, amidst a breakdown of co-operation and goodwill between the two parties, and in an attempt to express workers' grievances and reinforce the trade union's bargaining position, a strike can take place. It involves the application of naked force against management in an attempt to get them to agree to concede an employment decision against their wishes which cannot be resolved by negotiation. While the strike is not the only form of industrial action that can be used by trade unions to exert pressure on managers (for example, there is the overtime ban and work-to-rule) it is (apart from fullscale workplace occupations) the most visible and ultimately powerful means by which they can prevent managers from riding roughshod over workers' interests. Despite the fact that over the past two decades there has been a significant reduction in the incidence of strike action in many OECD countries, with historically low levels of industrial struggle in both the UK and US, strikes remain an important and enduring feature of trade union resistance. Moreover, the new wave of Europe-wide mass strikes recently, including the 2011 one-day public sector stoppage of 2.5 million workers in the UK, suggests a reassertion of the strength of union power and capacity for resistance via the strike weapon.

Arguably in many respects one of the most important factors pushing the balance of power in favour of workers is their self-activity, organisation and collective struggle in the 
workplace, with the level and character of strike activity an important measure of trade union confidence and power. It is true that the lack of strike action by strategically placed groups of workers might reflect their strength, not their weakness - in that employers may feel obliged to concede union demands to avoid conflict. Also the relatively higher propensity of strike activity in any particular industrial sector, organisation or enterprise might also reflect recalcitrant employers' policies as well as union strength (although often employers' policies are themselves formulated partly on the basis of workers' strength). In addition, strikes are only the most obvious means of exerting power and might on occasion be less effective than industrial action short of a strike or more political forms of leverage (Martin, 1992). But the fact remains that strikes often only take place when workers feel strong enough to challenge employers and - after taking into consideration whether they are offensive or defensive, victorious or defeated - they are, particularly in the context of 'labour quiescence' generally in advanced industrial societies over many years (Shalev, 1992), a particularly salient (if partial) barometer of the nature and extent of shop-floor trade union strength and power (Darlington, 1994: 35).

Of course, whether strikes take place or not is not dependent on the existence of trade union organisation; conversely even in countries where there is a relatively low membership, such as France, unions are capable of mobilising considerable numbers of workers and exerting significant pressure when they are seen as crucial intermediaries for public policies. To explain why strikes occur we have to consider the ('objective') underlying structural nature of the contradictory social relations between workers and management within capitalist society that can give rise to industrial conflict, the specific and genuine grievances and justifiable demands that can motivate workers to protest at managerial action (see, for example, Gouldner, 1955; Royal Commission, 1968; Bean and Stoney, 1986; Darlington, 2006), and the variety of potential power resources and 'opportunity structures' (Tilly, 1978; McAdam, 1996) which can limit or empower collective actors, including the economic and political situation, state of product and labour markets, industrial and organisational context, extent of management provocation and nature of bargaining power.

Nonetheless, it is not enough for workers just to hold a grievance for strike action to occur, and while structural factors create a more or less favourable environment for the collectivisation of the workforce, they do not in themselves necessarily generate strike activity. Rather, as mobilisation theory (Tilly, 1978; Kelly, 1998) has shown, the workers concerned must hold a collective sense of injustice, recognise that their interests are different from those of their employers, and attribute the source of their grievance to the actions of their employers. But crucially a mechanism needs to exist, in the form of activist leadership which channels that discontent into collective action. It is this function that trade unionism can often fulfil. Thus, even if trade union activists do not in any sense cause the underlying material conditions that lead to antagonism and strike activity, they do often play a crucial role in stimulating awareness of grievances and the potential for collective action for redress, and in proposing and initiating such action (Darlington, 2002a; 2006; 2009a; 2009b; 2012). In this sense union organisation and leadership can be seen to be as important as any structural or institutional complexity in shaping the nature of collective strike activity.

In terms of building trade union resistance a number of important potential positive characteristics of strikes have long been acknowledged. They can be a sign that workers 
have broken with a habit of submission and passivity, are beginning to question the authority of management and are willing to dare to defend their interests (Knowles, 1952; Turner et al, 1967; Eldridge, 1968; Beynon, 1973; Darlington, 1994). They can begin to cut though the competition that runs through the capitalist system that often divides workers on the basis of skill, gender and ethnicity, enabling workers to forge a common solidaristic identity against a common enemy, 'us and them' (Rogaly, 1977; Fantasia, 1988). They can give workers a sense of their own collective strength, demonstrating in practice the dependence of employers and the wider society on workers' labour; indeed it is the sheer impact of strikes - in terms of their capacity to disrupt/stop production of goods or services and thereby hit employers' profits - which explains the hostile counter-response they invariably engender (Lane and Roberts, 1971; Beynon, 1973; Thornet, 1987; Gall, 2003). They use workers' collective social power to force the employers to back down and to give ground, effectively obtaining immediate measurable material concessions over wages, jobs and conditions that would not otherwise have been achieved (Lane and Roberts, 1971; Franzosi, 1995; Darlington, 2009b; 20012; Darlington and Lyddon, 2001).

In this respect there is sometimes the assumption that the process of corporate globalisation has undermined workers' ability to stand up to multinationals. But while some multinationals can potentially close plants in one country and move operations to another to undermine trade union action, this is often not viable. Moreover, the technological and organisational changes of the last 25 years - such as the adoption by the world's car firms of Japanese 'just in time' system of keeping very low stocks of parts - can operate to workers' advantage, for example with strikes at individual General Motors plants in the US quickly shutting down company operations in other countries (Moody, 1997: 30-31). Meanwhile despite the fact that in the public sector strikes are primarily political, with even large-scale action not directly disrupting the workings of the economy or cutting profits, they can still put enormous pressure on the government ideologically and politically and in a mass campaign supported by wider layers of society force governments to make U-turns, as occurred in France in 1995 over plans to raise the pension age.

Another crucial potential feature of strikes is their link to building and strengthening trade union organisation (Friedman, 2008). Certainly there is much historical evidence to suggest that periods of dramatic rises in union membership and density have coincided exactly with upsurges of militant industrial struggle and/or strike 'waves', for example in Britain in the late 1880s, 1910-14 and 1968-74, as well as in the USA in the 1930s, France in 1936-37 and Poland in 1980-81. For example, in Britain trade union organisation was completely transformed by the 1910-14 'Labour Unrest', during which strike activity ran at more than four times the level of the previous decade, with trade union membership rocketing by 50 per cent from 2.1 million to 4.1 million (Holton, 1976: 73; Cronin, 1979: 93; Hinton, 1983: 84). Likewise between 1934 and 1937 American workers unleashed a strike wave in which the 'sit-down strike' became an essential weapon in the fight to build union organisation; union membership increased by 5 million with the formation of the Congress of Industrial Organisations ( $\mathrm{ClO})$ drawing in people who had never been seen as 'typical' union members - women and immigrant workers (Bernstein, 1970; Preis, 1972). In both countries 'unions became the beneficiaries of a virtuous circle of effectiveness and membership. As the scale of strike activity increased, so did the win rate, and as the win rate increased, bargaining coverage rose, more workers perceived unions to be effective and joined them, which in turn enabled them to be called...and so on' (Kelly, 1998: 101). 


\section{Revolutionary Potential of Trade Unionism}

One of the crucial reasons why Engels described the unions as 'schools of war' was because when they organise strikes they can have a profound radicalising effect on working class consciousness, by revealing the class nature of capitalist society and state power and the connection between the industrial struggle of one group of workers against their employer and the working class movement against the capitalist class as a whole (Lane and Roberts, 1971; Beynon, 1973; Eldridge, 1968; Hyman, 1972; Barker, 1987; Kelly, 1988), and ultimately the need for a socialist revolution that can usher in a new society based on workers' control. Of course, by no means do all strikes radicalise workers, and even when they do it may be only a small minority of workplace union activists affected (Gall, 2003: 260-65). The extent and breadth of radicalisation is often dependent on the size, duration and strength of the strike; on whether it is offensive or defensive, victorious or defeated; on the broader level of working class resistance within society; on how effective trade union officials (and social democratic party leaders) are in blocking or restraining action; and the effectiveness of radical socialist intervention and leadership (see below). Nonetheless during some historical periods (in the UK in 1915-22 and to a lesser degree 1968-74) there is evidence of trade union militancy over wages and conditions producing political class consciousness among quite wide layers of workers (Kelly, 1988) and in certain exceptional circumstances (Russia 1917, Germany 1919-23, Spain 1936, Portugal 1974-5) there have been periodic upsurges of revolutionary consciousness among millions of workers (Barker, 1987).

Significantly Lenin's What is to Be Done? (1902) has often been quoted out of context (Anderson, 1967; Clarke and Clements, 1977) to suggest that industrial struggle can only develop 'trade union consciousness' and does not lead to revolutionary class consciousness, thereby underlining the 'inevitable limitations' of trade unionism. Yet as with the pattern of Marx and Engels' observations the apparent contradictions between Lenin's writings on trade unionism were a reflection of the different contexts in which unions operated. Amidst the 1905 Russian revolution, when mass strikes swept St. Petersburg and combative trade unions came into existence, Lenin swung the emphasis very much in the opposite direction, emphasising the extent to which economic struggles could spontaneously become generalised and tend towards the class struggle with revolutionary political implications (Cliff, 1975; Harding, 1981; Lih, 2006). Likewise Rosa Luxemburg (1986), the Polish-German revolutionary Marxist, also drew out the importance of the 'mass strike' in the development of trade unions and the revolutionary movement, with the artificial separation between economic struggles (particularly over living and working conditions that touch on issues of control) and political goals (for the transformation of society) breaking down, with a reciprocal interaction between the two beyond the constricting limits of existing trade union (and reformist party) organisation.

As we noted earlier on, strikes are not the only form of anti-capitalist resistance. Other struggles, campaigns and mass social movements (whether organised local, nationally or internationally) can give people a collective sense of political identity and confidence, forge an importance sense of 'us and them', and win gains. Indeed, the 'labour upsurge' in America during the 1960s and 1970s was profoundly influenced by (and helped to influence) the great social movements that swept the era, above all the civil rights, Black Power, feminist, student and anti-Vietnam war movements. Significantly the contemporary international 'Occupy' movement against corporate greed and social inequality has been 
shaped in part by the legacy of a relative weak trade union movement; amidst a decline over many years in the incidence and apparent potency of collective trade union action based in the workplace, the street has for many new radicalised young people been viewed as the more appropriate public venue of protest. But the centrality of the workplace, of the point of production, is one of the most fundamental features of Marxism, both as a theory of society and as a strategy for socialist transformation. It is here that the wealth of society is generated, that exploitation - the daily extraction of surplus value - takes place, and here that the power of the capitalist class is based. Therefore, arguably any challenge to capitalism that is not rooted in the workplace or that adopts as its primary focus some aspect of the superstructure, be it parliament, local government, or the street is ultimately restricted to dealing with the outward manifestation of ruling class power not its inner source and is therefore likely to be severely constrained in its effect unless linked to the social weight and industrial power of the working class. As Luxemburg (1971a: 397) put it: 'Where the chains of capitalism are forged, there they must be broken'.

A graphic illustration of this was provided with the Egyptian revolution in early 2011. While the millions of people who demonstrated across the country and occupied Tahrir Square in Cairo seriously undermined the power of the regime, a crucial role was also played by successive waves of workers' strikes organised by new independent unions over the preceding four years which helped force the military to intervene to remove Mubarak. Since then, successive waves of workers' struggles have raised demands ranging from basic democratic slogans through to economic issues, which in turn have generated greater momentum for new political mobilisations. It is this dynamic, through which workers have sought not just to displace a dictator, but to shift the boundaries of democratic control in the workplace, that has created the potential for a shift from a political revolution to a social one, challenging the basis of capitalism (Naguib, 2011). As one Egyptian activist remarked: 'The union is a shield and our sword is the strike' (Shafiq, 2011)

In other words, in certain circumstances and historical periods mass strikes have the potential to not only paralyse the economy but also to stop large parts of the state itself from functioning, bringing together political and economic struggles into a revolutionary challenge to the capitalist system. They are what the international revolutionary syndicalist (or revolutionary union) movement ${ }^{1}$ that emerged in the early twentieth century, amidst an extraordinary upsurge in strike activity in many countries across the world, called 'revolutionary gymnastics'. For the syndicalists, strikes were training for the future social revolution which instructed workers in the realities of class struggle, exposed them to the viciousness of the employers, encouraged solidarity, reinforced class consciousness, and provided valuable lessons for the greater revolutionary battles to come. Moreover they helped increase workers' confidence to change society themselves rather than relying on

\footnotetext{
${ }^{1}$ Of course 'syndicalism' is necessarily only a very broad term for a number of related but rather different revolutionary union movements that flourished across the world in a variety of national forms which utilised contrasting terms, including: 'revolutionary syndicalism' (France and Britain), 'industrial unionism' (America) and 'anarcho-syndicalism' (Spain and Italy). Nonetheless, arguably the colloquial description of such different movements as 'syndicalist' is both useful and justified because it draws attention to basic fundamental ideological and practical similarities between them notwithstanding the specific strategic approaches and organisational forms adopted by individual movements (Darlington, 2008: 4-7).
} 
trade union officials or parliamentary representatives to do it for them (Darlington, 2008: 38-9).

Significantly the syndicalists had a dual conception of the trade unions as both an organ of struggle in the present and an instrument of revolution and embryo of the new hoped-for classless society of the future. On the one hand, they believed the raison d'être of the trade unionism was the organisation of workers against employers, standing at the very point where the class struggle arises and challenges the class enemy. That meant seeking every opportunity to defend and improve workers' wages, hours and conditions of work in their everyday struggle against specific employers. On the other hand, they believed the unions could be transformed into militant organisations dedicated to fighting for the entire working class with the overall objective of overthrowing capitalism and establishing a new society. The road to the emancipation of the working class lay through an intensification of the industrial struggle to its logical culmination in a revolutionary general strike that would overthrow the capitalist system and replace it by workers' control of industry and society exercised by the trade unions. As the Confédération Générale du Travail's (CGT) 1906 Charte d'Amiens stated: 'The trade union, which is today a fighting organization, will in the future be an organisation for production and distribution and the basis for social reorganisation.'

Although 'classical' revolutionary syndicalism no longer exists as a major organised force within the international union movement, various 'quasi-syndicalist' tendencies have re-emerged in more recent years in some of the most powerful and radical workers' movements in the world, including South Africa and Brazil during the mid-1980s. One of the most notable examples was the Solidarity movement in Poland in 1980-1, with its explicit commitment to class warfare as the central means by which to change society combined with a conception of the union as the main vehicle of revolutionary struggle to overthrow the Communist Party-dominated state bureaucracy (McShane, 1981; Barker, 1986; Darlington, 2002b).

\section{Limitations of Trade Unionism}

As previously signaled, the profoundly contradictory nature of trade unionism within capitalism means that the potential strengths outlined above are merely one side of the competing logics at work: any fully-rounded analysis also needs to consider the very real limitations to trade union resistance to capitalism.

First, there is sectionalism. Thus whilst trade unions unite workers in a common labour process, they also divide them since the boundaries of any individual union encompass only a fragment of the working class. As organisations built on particular trades or industries, they mirror the divisions imposed on workers by the capitalist system, with the very name trade unionism implying sectionalism. Just as workers in various industries earn different wages and operate under different conditions of employment, trade unions only embrace certain categories of workers as members and exclude others, with a primary concern with the particular occupation or sectoral interests of those they represent rather than the working class as a whole. Hence the divisions between blue collar and white collar workers, private and public sector workers, teachers in one union and railway workers in 
another, and even between different unions in the same industry. Each of these different (often competing) unions tends to adjust to capitalism in a piecemeal, ad hoc way rather than as a movement (Lane, 1974: 267), pursuing their own sectional claims against specific employers without reference to others (reflected in the fragmented structure of collective bargaining) rather than coordinating workers' organisation into a broader anti-capitalist front. The occasional public sector wide/national strike that embraces a number of different unions does not fundamentally change this underlying sectionalist feature. In addition, unions have often failed to confront, or seek or build structures and policies to overcome, the ethnic and gender inequalities within the employment relationship

Second, as Marx and Engels argued, even though trade unions provide the means and instrument through workers' resistance to capitalism can be organised, they seek merely to improve the terms of workers' subordination to managerial control within the existing framework of society, opposing the symptoms rather than the underlying causes of workers' exploitation. 'As institutions, trade do not challenge the existence of a society based on a division of classes, they merely express it...They can bargain within the society, but not transform it' (Anderson, 1967: 264-5). Hence the curious phenomenon of 'antagonistic co-operation': the constant interpenetration of conflictual and co-operative aspects of trade unionism (Hyman, 1974: 258). Their 'dual character' means that at one and the same time they resist capitalist exploitation and function as a source of social order which helps stabilise capitalist society (Zoll, 1976).

Third, there is the problem of trade union bureaucracy (Luxemburg, 1986; Michels, 1915; Webbs, 1920). By confining the class struggle to the search for reforms within the framework of a capitalist society there is a presumption that the interests of capital and labour can be accommodated, with the consequence that workers' struggles, however militant, must ultimately result in a compromise. It is this situation which generates a permanent apparatus of full-time union officials who specialise in negotiating the terms of such compromises - a 'union bureaucracy' that occupies a unique social position with interests, perspectives and resources different from, and sometimes in antagonism to, the bulk of the rank-and-file members they represent (Darlington and Upchurch, 2012). Crucially full-time union officials are subject to enormous pressure to preserve the tolerance of employers and governments by establishing a stable and co-operative bargaining relationship, and therefore to subordinate the autonomous and informal activity of workers to limit managerial prerogative by channelling grievances into innocuous forms, defining bargaining issues within a narrow focus so as to render the task of achieving compromise more tractable (Hyman, 1975b: XXV; 1984: 141). As a result, union officials often tend to view strike activity which pushes 'too far' and unduly antagonises employers and the state as an unwelcome disruption to stable bargaining relations. This can lead them to act as 'manager[s] of discontent' (Mills, 1948: 9), ending strikes on 'compromise' terms detrimental to rank-and-file aspirations (Hartley et al, 1983: 150; Melvern 1986: 187; Bramble, 1995; Gall, 2003: 175-179).

Full-time union officials are not simply 'fire extinguishers of the revolution' (Anderson, 1967: 277). Depending on the pressures on them from employers and government on the one hand, and their own members on the other, officials (even rightwing officials) do sometimes threaten or organise strike action. The central problem is that 
whilst the rank-and-file of the union have a direct interest in fighting against the exploitation of employers and government, and indeed have everything to be gained by fighting for the success of militant strikes, full-time officials have a vested interest in the continued existence of a system upon which their livelihood and position depends, and so end up trying to reconcile the interests of labour and capital, which usually leads them to temper workers' resistance. While ideological and political differences between 'left' and 'right-wing' officials can be important in influencing their behaviour, they are secondary to the much more fundamental common material social role, position and interests which bind all officials together as a distinct social group (Cliff and Gluckstein, 1986: Darlington and Upchurch, 2012). As the British 1926 General Strike confirmed, the in-built structural pressures mean that at the end of the day left-wing officials are just as capable of holding back workers' struggles as their right-wing counterparts.

Fourth, there can be significant potential limitations to strike activity as a means of trade union resistance to capitalism. Even significant concessions over wages, conditions and jobs are inevitably vulnerable to the vicissitudes of the market and economy, and the repeated nature of employers' counter-attacks and their impact on the balance of power and workers' confidence to resist. Thus Luxemburg (1971b: 105) compared trade unionism to the 'labour of Sisyphus', who in Greek legend was condemned to push a huge boulder up a hill only to watch adversaries roll it back down again. Moreover strike action in a nonrevolutionary period does not usually challenge or alter property relations in society. Even a mass strike that emerges through spontaneous rank-and-file struggle from below (such as in France and Spain 1936 and France 1995) as opposed to a bureaucratic mass strike called on and off by officials from above (such as the British 1926 General Strike), whilst it can seriously undermine the functioning of capitalism, does not automatically abolish it and create a new economic, social and political order.

Fifth, trade unions imitate their adversary, reflecting back capitalism's sharp demarcation between 'economics' and 'politics'. Put crudely this leads to an attitude which argues that trade unions should narrowly constrain themselves to the pursuit of the economic struggle in the workplace over wages and conditions, while for political change in society workers must look to social-democratic parties to act through the parliamentary process on their behalf. It encourages the belief that the class struggle between capital and labour is a de-politicised, economic and social issue and that workers' interests are best served through negotiation and reform rather than through the revolutionary transformation of society. The idea the unions might attempt to utilise industrial militancy for political ends to challenge the government is completely rejected. For example, in Britain loyalty to the Labour Party, especially when Labour is in office, has encouraged government ministers to place pressure on unions not to undermine 'their' government with industrial disputes, and even when out of office the Labour Party has been able to pressurise them into dampening down strike action on the basis that this would harm electoral prospects (Miliband, 1972; Coates, 1975; 1989; Taylor 1989; 1993).

It follows from the different limitations outlined above that, because of their very function of negotiation and accommodation with capitalism, the anti-capitalist and revolutionary potential of trade unionism is severely constrained. As Hyman (1989: 250-1) explained, they operate in an environment of hostile forces which condition and distort 
their character and dynamics: bureaucracy, collaboration, sectionalism and economism are all reflections of powerful and often overwhelming tendencies, albeit they are not uncontradictory and irresistible forces. The different polar opposites in the nature of trade unionism - between conflict and accommodation - are not a fixed proposition in terms of an 'either/or' logic, but constantly in motion reflecting and at the same time changing the social condition of which it is part. The result is a continuum of possible and overlapping responses, each dominant to a greater or lesser degree within individual unions and changing over time. Thus the contrast between the militancy of unions generally in the UK and US in the 1970s (combined with important continuing elements of conservatism) compared with the early 1980s onwards when accommodative tendencies predominated (combined with important elements of militancy). As Antonio Gramsci (1977: 265), the Italian revolutionary Marxist, wrote:

The trade union is not a predetermined phenomenon. It becomes a determinate institution; it takes on a definite historical form to the extent that the strength and will of the workers who are its members impress a policy and propose an aim that defines it.

The key point being repeated here is that it is the changing balance of class forces between capital and labour that has a profound impact on the nature of trade unionism and its role and ability to mount resistance to capitalism, in terms of which side is more confident, stronger and successfully pushing the frontier of control to their advantage within the workplace and society more broadly.

\section{Identity and Orientation}

We can now briefly turn our attention to some of the more concrete manifestations of the different models of unionism that have developed both historically and comparatively, as well as some contemporary issues of union strategy. To begin with, as a means of conceptualising broad national historical variations in trade union identity and ideology, Hyman (2001) uses the notion of the 'geometry' of trade unionism to argue that trade unions in Europe (and perhaps more widely) have had three distinct strategic and tactical orientations around the axis of 'market', 'class' and 'society'.

Market: this is a form of 'business unionism' in which unions' rely upon collective bargaining to achieve their goals which are largely related to 'bread and butter' concerns of immediate pay and conditions, with an arm's-length relationship between the sphere of party politics and that of trade union action. It is a form of what Samuel Gompers, who founded the American Federation of Labor (AFL), termed 'pure-and-simple unionism', exemplified by the attempt made by many American unions in the 1950s to seek collaborative relationships with employers, and still practiced today by some unions both in the US and elsewhere.

Society: this is a form of social-democratic unionism, typically to be found in countries such as Germany, the Netherlands and Britain, in which they are vehicles for social integration that has as a priority raising workers' status and promoting gradual improvements in social welfare and social cohesion. While collective bargaining is of importance, such unions also have strong links with social democratic political parties and 
parliamentary reform is viewed as a key instrument for achieving favourable conditions of work and life.

Class: this is a form of class struggle and anti-capitalist unionism characterised by the embrace of strikes and socio-political protest. Unions are viewed as being in an irreconcilable struggle between capital and labour; they act as an agency which ultimately can be effective only as a means of collective mobilisation of the working class, with the ultimate objective of a revolutionary transformation of society. While historically syndicalist, socialist and communist unions (Darlington, 2008), for example, the CGT in France and IWW in America in the early twentieth century, would fall under this category, so today would SUD-Rail in France and the RMT in Britain (Connolly, 2010; Connolly and Darlington, 2012; Darlington 2009a; 2009b).

Whilst every trade unions faces in all three of these directions and cannot afford to ignore any of the orientations, particular histories and social frameworks lead to different tensions emerging in varying institutional contexts, with contrasting union movements having a tendency to prioritise different identities. Nonetheless the three models represent merely 'ideal types' of unions which are rarely, if ever, see in practice, leading Hyman (2201: 4) to assert that most union have 'tended to incline towards an often contradictory admixture of two of the three ideal types). Thus market-based 'bread-and-butter' unionism cannot altogether neglect the broader social and political context of market relations; civil society based social-partnership unionism cannot water itself down indefinitely in collaborative integration; and class unionism cannot avoid having to deliver some shortterm economic results for their members and accommodating with the existing social order.

It should be noted that while there are a number of factors influencing the nature and extent of democracy within trade unions, including the degree of membership homogeneity, extent of skill, status and educational qualifications, strength of occupational identity, and size and distribution of membership, union government is also affected by the prevailing conception of union purpose, whereby the broader and more ambitious the union's objectives, the more likely the members will become active participants. For example in the UK the RMT's adversarial unionism has been both cause and effect to such democratic tendencies. The attempt to regularly mobilise members to take strike action, the vigorous encouragement of membership activism, the union organising drive, and the broader left-wing politically-informed objectives that shape union policy have encouraged democratic processes, and in turn such democratic processes have helped to shape the union's approach, its organising success and the energising of the activists (Darlington, 2009a; 2009b; 2012).

Upchurch et al (2009) have identified the way in which, with neo-liberal marketisation becoming the dominant modus operandi of western European governments, there has developed a 'crisis of social democracy' as social-democratic parties have increasingly accommodated themselves to neo-liberal imperatives. This has been paralleled by a potential 'crisis of the social democratic model of trade unionism' which predominated in many countries. In response, there has emerged a minority 'radicalised political unionism' tendency - for example, the SUD movement in France, the independent unions focused on workers' centres in Greece, and among sections of the IG Metall and Ver.di unions in 
Germany - characterized by a rejection of neo-liberalism and a break to the left from social democracy. It is associated with the repetitive mobilisation of members through strike action, left oppositionist leadership, the use of less bureaucratically-controlled forms of trade union action, and an attempt to engage members beyond the workplace in new social movements and networks against globalisation and privatisation. Crucially, even though it is often overlooked in studies on trade union renewal and revitalisation strategies, the fortunes of such 'radicalised political unionism' as a viable alternative identity and its subsequent consolidation is likely to be intricately connected with the development of an alternative left-wing political leadership and class-based notions of trade unionism as the pathway to both advancing workers' interests and to revitalising union organisation (Connolly and Darlington, 2012).

Meanwhile, In terms of building the potential for union resistance there is clearly the need to organise and recruit many more new union members, particularly among the enlarged periphery of casual, short-term, insecure, and poorly-paid workforce. But while it is often claimed the growing importance of women and ethnic minority workers, service work, part-time and other 'atypical' forms of employment has led to the fragmentation of worker interests, placing pressures on the construction of traditional solidaristic union identities and interests, Hyman (2001: 165) has acknowledged 'differentiation, division and disunity have been omnipresent features of trade union development'. Moreover, there remain possibilities for unions to 're-imagine' their interests, to move away from the building of mechanistic solidarities where collective interests are determined and expressed relatively narrowly by core groups, and to develop more organic solidarities which integrate and promote a far broader and diverse set of interests and identities of a changing workforce and membership, and which unite different groups of workers both within and between workplaces. But to do this, unions need to change the emphasis from workplace-solidarities to embrace class-based solidarities - with class becoming a 'rallying cry' for understanding, expressing and promoting the commonality of workers' distinct interests in opposition to capitalism (Simms, 2012). In this fashion unions could assert their identity as a 'sword of justice', campaigning over broad social and political concerns and contesting oppression, inequality and discrimination in all its forms.

With such considerations in mind, 'social movement unionism' (SMU) has often been presented as a model on which trade unions might re-invent their identities to survive and thrive in a hostile global environment (Waterman, 1998; Robinson, 2000; Clawson, 2003). Emphasising the need for trade unions, which many people view as essentially representatives of 'old labour', to begin to work in alliance with other agents in civil society, SMU has stood out as an alternative pathway for unions that seeks to revitalise the autonomous, inclusive and critical dimensions of their practice in contrast to the subordinate, exclusive and uncritical practices of 'business unionism' and 'social partnership'. Thus Waterman (1998: 203) has argued that because 'a complex high-risk globalised information capitalism' has undermined the capacity to develop an effective labour movement around a class identity, unions should link with non-labour organisations (the 'new alternative social movements') to form a global social movement that can rise to the challenge of the 'immediate necessity of civilising a capitalist world order (p. 2). 
Yet as some otherwise sympathetic critics have pointed out, while unions undoubtedly need to build links with broader social movements, there is an implicit tendency within the SMU strategic approach to relegate the trade union struggle in the workplace to the status of merely one among many others (Mathers, 2007; Upchurch and Mathers, 2011), in the process effectively endorsing the view that there is no longer anything special about workers' collective exploitation and resistance at work which creates labour's unique potential to transform the world. Likewise, rather than counterposing a supposedly declining, conservative organised working class to the genuine radicalism on the streets or among 'precarious' workers as some commentators have done (Standing, 2011; Mason, 2012), the real task is to bring together the radical energy, creativity and initiative of the young protestors on the streets with the day-to-day struggles and collective power of organised workers in their trade unions.

\section{Some Conclusions and Further Reflections}

Despite the decline in membership that many unions have experienced in different countries around the world during the past 30 years, the rationale for the collective representation of workers as a means of building resistance to capitalism - namely their distinct set of interests and asymmetry of power vi-a-vis the employers - remains. This suggests that, notwithstanding the pressures of globalisation and neo-liberalism, the fundamental basis for trade union recovery remains present. The new wave of mass strikes and demonstrations that have occurred across Europe recently has both underlined unions' enormous power and continuing relevance as well as the possibilities that exist for a revival of their fortunes.

Ironically for years many commentators have argued that the only feasible way for unions to maintain, let alone develop, their influence within the workplace, amidst the transformed world of work and Human Resource Management, is by behaving moderately and entering into partnership relationships with employers, effectively eschewing adversarial relations in favour of more consensual relations designed to produce 'mutual gains' for both parties (Roche and Geary, 2006). Yet arguably such 'strategies of retreat' (Moody, 2012: 24), which have characterised the decisions and practices of many union leaders in different countries, have merely seriously weakened trade unionism and left it vulnerable to employers' attacks because it has eroded the willingness and capacity of members to resist and to challenge employer demands. In the current 'Age of Austerity' the potential relationship between trade union militancy, effectiveness in protecting workers' interests, membership growth and union revitalisation could become more evident.

Nonetheless, for all the reasons we have explored, trade unionism is essentially oriented on merely coming to terms with the power of capital rather than attempting to overthrow that power. Thus the universal tension that has been identified between the contradictory elements of 'movement' and 'organisation' (Herberg, 1943; Hyman, 2001; Cohen, 2006). On the one hand, trade unionism as an organisation enshrined in formal, official and often bureaucratic 'representative' structures that prioritise collective bargaining and institutional survival (the protection of material and financial assets). On the other hand, trade unionism as a movement, an organisational form that prioritises 
workplace resistance, direct democracy, membership mobilisation and radical economic and political aspirations. In other words, while there are some features of revolutionary potential to trade unionism, their accompanying in-built limitations mean that on their own they cannot be the vehicle of capitalism's abolition.

Clearly strong rank-and-file organisations within the unions are absolutely crucial to the task of building effective resistance inside the working class movement. For example, during an upturn in the level of workers' militancy in Britain in the early late 1960s and early 1970s, strong independent workplace union organisations, often in the form of the shop stewards' system of lay representation of rank-and-file members, acted as an important counteracting tendency against the bureaucratisation and accommodation of official union leaderships (Darlington and Lyddon, 2001). While they have not been immune from similar pressures towards accommodation and bureaucracy affecting full-time union officials, and with their confidence to organise independently of officials from below considerably undermined in the wake of the massive strike defeats that occurred in the 1980s and 1990s, shop stewards and other lay workplace union reps have generally remained qualitatively different from officials in their potential responsiveness to rank-and-file pressure (Darlington, 2010; Darlington and Upchurch, 2012). If the recent Europe-wide revival of industrial struggle and trade union confidence is sustained, it raises the possibility for the revitalisation of such rank-and-file organisation.

An important historical model was provided by the way in which during the First World War networks of local shop stewards were able to operate both within and outside official union structures, walking on two legs, official and unofficial, to transform shop stewards' fragmented forms of organisation in different workplaces into a national rankand-file movement which linked together hundreds of thousands of workers across the engineering industry, and thereby provide an alternative leadership to the full-time union officials that could act independently of them. As the Clyde Workers' Committee declared in 1915: 'We will support the officials just so long as they rightly represent the workers, but will act independently immediately they misrepresent them' (Hinton, 1973). Almost a century later, this remains a useful guide to how the relationship between rank-and-file workers and full-time union officials can work, with union activists focusing less on attempting to capture the union machine (by electing left wing officials into office) than on fostering independent collective action by workers themselves.

Nonetheless from a Marxist perspective, no trade union organisation, however militant, is enough to defeat capitalism. Workers' struggles can deal with the power of the capitalist class only if they break out of the confines of trade unionism. Only by ignoring the division of economics and politics and by making their target the capitalist state can the working class hope to win a lasting victory. But despite the fact that in periods of mass struggle the division between economic and political issues can break down, there is an 'organisational condition' for this to become durable and far-reaching. Hence the role of radical left political parties and groupings (such as Syriza in Greece, Front de Gauche in France and Die Linke in Germany). There will be a need for new layers of political militants, motivated by ideologies of social justice, who are able to take up not only workers' immediate struggles over pay, conditions, jobs and pensions, but also broader political questions about the crisis of political legitimacy; who can link trade union industrial 
struggles to a concerted anti-capitalist movement that has as its central strategic aim the need to overthrow the existing system. In the process, such left-wing political trade unionism can begin to provide a political and organisational alternative to social-democratic politicians and official union leaders.

Furthermore, historical evidence suggests that within certain extraordinary revolutionary situations there is the potential for rank-and-file movements to develop into new types of bodies of workers' power which can supplement or even supplant the unions to challenge the economic and political power of the ruling class - in a similar fashion to the workers' councils (or 'soviets) that became a central feature of the Russian revolutions of 1905 and 1917, the revolutions in Germany, Hungary and Italy in 1919-20, and during the Spanish Civil War of 1936, as well as in other countries in more recent times such as Poland 1980-1.

In conclusion, while trade union bureaucracies and social-democratic parties are essential shock-absorbers for modern capitalism and its states, because of their capacity to smooth out and contain opposition, at various times different balances are struck between conflict and accommodation in workers' action and consciousness, and given that the seedbed of class conflict is re-sown and re-fertilised by the everyday experience of exploitation, the containment of workers' resistance to capitalism is anything but a simple and automatic process, even in quiet times (Barker, 1987: 222). At the same time as the Occupy movement of resistance to global corporate power and social inequality has reignited a debate about the very nature and legitimacy of capitalism as a form of society, trade union struggle is also returning to the centre stage, with the rising curve of resistance to government austerity measures in many European countries putting the organised working class back on the agenda as a fundamental agent of change in society.

\section{References}

Anderson, P, (1967) 'The Limits and Possibilities of Trade Union Action', in R. Blackburn and A. Cockburn (eds.) The Incompatibles, Harmondsworth: Penguin.

Barker, C. (1986) Festival of the Oppressed: Solidarity, Reform and Revolution in Poland 1980-81, London: Bookmarks.

(1987) 'Perspectives', in C. Barker (ed.), Revolutionary Rehearsals, London: Bookmarks, pp. 217-45.

Bean, R., and P. Stoney (1986). 'Strikes on Merseyside: A Regional Analysis'. Industrial Relations Journal, 17(1): 9-23.

Bernstein, I. (1970) Turbulent Years: A History of the American Worker 1933-1941, Boston: Houghton Mifflin.

Beynon, H. (1973) Working for Ford, Harmondsworth: Penguin. 
Bramble, T. (1995) 'Deterring Democracy? Australia's New Generation of Union Officials', Journal of Industrial Relations, 37: 401-26.

Brenner, A. R. Brenner and C. Winslow, eds. (2010) Rebel Rank and File: Labor Militancy and Revolt From Below During the Long 1970s, London: Verso.

Clarke, T., and L. Clements, eds. (1977) 'The Raison D'être of Trade Unionism', in Trade Unions Under Capitalism. Glasgow: Fontana/Collins, pp. 7-23.

Clawson, D. (2003) The Next Upsurge: Labor and the New Social Movements, Ithaca; ILR Press.

Cliff, T. (1975) Lenin, Vol. 1: Building the Party, London: Pluto Press.

Cliff, T. and D. Gluckstein (1986) Marxism and the Trade Union Struggle The General Strike of 1926, London: Bookmarks.

Coates, D. (1975) The Labour Party and the Struggle for Socialism, Cambridge University Press.

Cohen, S. (2006) Ramparts of Resistance: Why Workers Lost Their Power and How to Get it Back, London: Pluto Press.

Connolly, H. (2010) Renewal in the French Trade Union Movement: A Grassroots Perspective. Oxford: Peter Lang.

Connolly, H. and R. Darlington (2012) 'Radical Political Unionism in France and Britain: A Comparative Study of SUD-Rail and the RMT', European Journal of Industrial Relations, 17 (4), forthcoming.

Cronin, J.E. (1979) Industrial Conflict in Modern Britain, London: Croom Helm.

Darlington, R. (1994) The Dynamics of Workplace Unionism. London: Mansell.

- (2002a) 'Shop Stewards' Leadership, Left-Wing Activism and Collective Workplace Union Organization'. Capital and Class, 76: 95-126.

(2002b) 'Revolutionary Syndicalism: Classical and Contemporary Forms', Paper presented to 4th European Social Science History Conference, Netherlands Congress Centre, The Hague, Holland, 27 February-2 March.

. (2006) 'Agitator “Theory" of Strikes Re-Evaluated', Labor History, 47 (4): 485-509.

. (2008) Syndicalism and the Transition to Communism: An International Comparative Analysis, Aldershot: Ashgate.

. (2009a) 'Leadership and Union Militancy: The Case of the RMT', Capital and Class, 33(3): 3-32. 
. (2009b) 'Organising, Militancy and Revitalisation: The Case of the RMT', in (ed.) G. Gall, Union Revitalisation in Advanced Economies: Assessing the Contribution of 'Union Organising', Houndmills: Palgrave Macmillan, pp. 83-106.

. (2010) 'The State of Workplace Union Reps Organisation in Britain Today', Capital and Class, 34 (1): 126-135.

. (2012) 'The Interplay of Structure and Agency Dynamics in Strike Activity', Employee Relations, forthcoming.

Bookmarks.

and D. Lyddon (2001) Glorious Summer: Class Struggle in Britain, 1972, London: . and M. Upchurch (2012) 'A Reappraisal of the Rank-and-File versus Bureaucracy Debate', Capital and Class, 36 (1): 77-95.

Dundon, T. and D. Rollinson (2011) Understanding Employment Relations, London: McGrawHill Higher Education.

Eldridge, J.E.T. (1968) Industrial Disputes: Essays in the Sociology of Industrial Relations. London: Routledge.

Engels, F. (1969) The Condition of the Working Class in England, St. Albans: Panther.

Fantasia, R. (1988) Cultures of Solidarity: Consciousness, Action and Contemporary American Workers. Berkley: University of California Press.

Flanders, A. (1970) 'Trade Unions in the Sixties', in A. Flanders (ed.) Management and Union: The Theory and Reform of Industrial Relations, London: Faber.

(1975) Management and Unions: The Theory and Reform of Industrial Relations, London: Faber and Faber.

Franzosi, R. (1995) The Puzzle of Strikes: Class and Class Strategies in Postwar Italy. Cambridge: Cambridge University Press.

Friedman, G. (2008) Reigniting the Labor Movement, London: Routledge.

Gall, G (2003) The Meaning of Militancy? Postal Workers and Industrial Relations. Aldershot: Ashgate.

Gall, G. A. Wilkinson and R. Hurd (eds.) The International Handbook of Labour Unions: Response to Neo-Liberalism, Cheltenham: Edward Elgar.

Goodrich, C. L. (1975) The Frontier of Control, London: Pluto Press.

Gouldner, A. W. (1955) Wildcat Strike: A Study in Worker-Management Relations. New York: Harper Torchbooks. 
Gramsci, A. (1977) 'Unions and Councils', in Selections from Political Writings 1910-1920, London: Lawrence and Wishart, pp. 265-268.

Harding, N., (1981) Lenin's Political Thought: Vol. 2: Theory and Practice in the Socialist Revolution, New York: St Martin's Press.

Hartley, J. J. Kelly and N. Nicholson (1983) Steel Strike: A Case Study in Industrial Relations, London: Batsford.

Herberg, W. (1943) 'Bureaucracy and Democracy in Labor Unions', Antioch Review 3: 405417.

Hinton, J. (1973) The First Shop Stewards' Movement, London: Allen and Unwin.

. (1983) Labour and Socialism: A History of the British Labour Movement 1867-1974, Brighton: Wheatsheaf Books.

Holton, B. (1976) British Syndicalism 1900-1914, London: Pluto Press, 1976.

Hyman, R. (1971) Marxism and the Sociology of Trade Unionism, London: Pluto Press. . (1972) Strikes, London: Fontana.

78. . (1974) 'Workers' Control and Revolutionary Theory', Socialist Register, 11, pp. 241. (1975a) Industrial Relations: A Marxist Introduction, Basingstoke: Macmillan. (1975b) 'Foreword to the 1975 Edition', in C.L. Goodrich [first published 1920] The Frontier of Control: A Study in British Workshop Politics, London: Pluto Press, pp. vii-xli. (1980) 'Trade Unions, Control and Resistance', in G. Esland and G. Salaman (eds.) The Politics of Work and Occupations, Milton Keynes: Open University Press, pp. 303-34.

(1989) 'Class Struggle and the Trade Union Movement', in The Political Economy of Industrial Relations, London: Macmillan, pp. 224-53.

(2001) Understanding European Trade Unionism: Between Market, Class and Society, London: Sage.

Kelly, J. (1988) Trade Unions and Socialist Politics, London: Verso, 1988.

(1998) Rethinking Industrial Relations. Rethinking Industrial Relations: Mobilisation, Collectivism and Long Waves. London: Routledge.

Knowles, K.G.J.C. (1952) Strikes: A Study in Industrial Conflict. Oxford: Blackwell. Lane, T. (1974) The Union Makes Us Strong, London: Arrow Books.

Lane, T. and K. Roberts (1971) Strike at Pilkingtons. London: Fontana. 
Lenin, V. I. (1970: first published 1906) 'What is to be Done?', Selected Works: Vol. 1, Moscow: Progress, pp. 122-270.

Lih, L. T. (2006) Lenin Rediscovered: 'What is to be Done?' in Context, Brill: Historical Materialism.

Luxemburg, R. (1986) The Mass Strike, the Political Party and the Trade Unions, London: Bookmarks.

. (1971a) 'Our Programme and the Political Situation', Selected Political Writings, New York: Monthly Review Press, pp. 377-408.

(1971b) 'Social Reform or Revolution', Selected Political Writings, New York: Monthly Review Press, pp. 52-134.

McAdam, D. (1996) Conceptual Origins, Current Problems, Future Directions, in: D. McAdam, J.D. McCarthy, M.Y. Zald (eds.), Comparative Perspectives on Social Movements. Political Opportunities, Mobilizing Structures, and Cultural Framings, Cambridge University Press, pp. 23-40.

McShane, D. (1981) Solidarity: Poland's Independent Union, Nottingham: Spokesman.

Martin, R. (1992) Bargaining Power, London: Clarendon Press.

Marx, K. (1970) 'Wages, Price and Profit', in K. Marx and F. Engels, Selected Works, Moscow: Progress. pp. 185-226. (1973) The Poverty of Philosophy, Moscow: Progress Publishers.

Mason. P. (2012) Why It's Kicking off Everywhere: The New Global Revolutions, London: Verso.

Mathers, A. (2007) Struggling for a Social Europe: Neoliberal Globalisation and the Birth of a European Social Movement, Aldershot: Ashgate.

Melvern, L. (1986) The End of the Street, London: Methuen.

Michels, R. (1915) Political Parties: A Sociological Study of the Oligarchical Tendencies of Modern Democracy [republished New York: Collier Books, 1962].

Miliband, R. (1972) Parliamentary Socialism: The Politics of Labour, London: Merlin Press.

Mills, C. W. (1948) The New Men of Power: America's Labor Leaders, New York: Harcourt Brace.

Moody, K. (1997) Workers in a Lean World: Unions in the International Economy, London: Verso. 
. (2012) 'Contextualising Organised Labour in Expansion and Crisis: The Case of the US', Historical Materialism, 20 (1): 3-30.

Naguib, S. (2011) The Egyptian Revolution: A Political Analysis and Eyewitness Account, London: Bookmarks.

Preis, A. (1972) Labor's Giant Step: Twenty Years of the CIO, New York: Pathfinder Press.

Robinson, I. (2000) 'Neoliberal Restructuring and US Unions: Towards Social Movement Unions', Critical Sociology, 26 (1/2): 109-138.

Roche, W.K. and J.F. Geary (2006) Partnership at Work: The Quest for Radical Organisational Change, London: Routledge.

Rogaly. J. (1977) Grunwick. Harmondsworth: Penguin.

Royal Commission on Trade Unions and Employers' Associations (1968) Report. Cmnd 3624. London: HMSO.

Shafiq, M. (2011) 'The Union is Shield And Our Sword is the Strike', Socialist Review, 364: 2224.

Shalev, M. (1992). 'The Resurgence of Labour Quiescence', in M. Regini (ed.) The Future of Labour Movements. London: Sage, pp. 102-132.

Simms, M. (2012) 'Imagined Solidarities: Where is Class in Union Organising?', Capital and Class, 36 (1): 97-115.

Sisson, K. (2009) 'Industrial Relations and the Employment Relationship', in R. Darlington (ed.) What's the Point of Industrial Relations? In Defence of Critical Social Science, Salford: BUIRA.

(2010) Employment Relations Matters:

http://www2.warwick.ac.uk/fac/soc/wbs/research/irru/erm/

Standing, G. (2011) The Precariat: The New Dangerous Class, London: Bloomsbury Academic.

Taylor. A.J. (1989) Trade Unions and Politics: A Comparative Introduction, Houndmills: Macmillan.

Taylor, R. (1993) The Trade Union Question in British Politics: Government and Unions Since 1945, Oxford; Blackwell.

Thornett, A. (1987) From Militancy to Marxism. London: Left View Books.

Tilly, C. (1978) From Mobilization to Revolution. New York: McGraw-Hill.

Turner, H.A., G. Clack, and G. Roberts. (1967) Labour Relations in the Motor Industry. London: Allen and Unwin. 
Upchurch, M., G. Taylor and A. Mathers (2009) The Crisis of Social Democratic Trade Unionism in Western Europe: The Search for Alternative, Aldershot: Ashgate.

Upchurch, M. and A. Mathers (2011) 'Neoliberal Globalisation and Trade Unionism: Toward Radical Political Unionism?', Critical Sociology, 38 (2): 265-80.

Waterman, P. (1998) Globalisation, Social Movements and the New Internationalisms, London: Mansell.

Webster, E. (1988) 'The Rise of Social Movement Unionism: The Two Faces of Black Trade Union Movements in South Africa', in P. Frankel et al (eds.) State, Resistance and Change in South Africa, London: Croom Helm, pp. 174-196.

Webb, S. and B. Webb (1920) History of Trade Unionism 1666-1920, London: Longmans, Green and Co.

Zoll, R. (1976) Der Doppelcharakter der Gewerkschafen, Frankfurt: Suhrkamp. 